\title{
ANALISIS CAPAIAN LITERASI SAINS BIOLOGI SISWA SMA KELAS X DI KOTA PADANG
}

\author{
Fadhilatul Huryah ${ }^{1)}$, Ramadhan Sumarmin ${ }^{2)}$, Jon Effendi ${ }^{3)}$ \\ ${ }^{1)}$ PPS Pendidikan Biologi, FMIPA Universitas Negeri Padang \\ ${ }^{2)}$ Staf Pengajar Jurusan Biologi, FMIPA Universitas Negeri Padang \\ ${ }^{3)}$ Staf Pengajar Jurusan Kimia, FMIPA Universitas Negeri Padang \\ fadhilatulhuryah@gmail.com \\ ramadhan_unp@yahoo.com
}

\begin{abstract}
Based on the results of PISA in 2000-2009, the score of Indonesian students' science literacy with the average score was 500. The low score of Indonesian students' acquisition is reflecting the poor performance of Indonesian students in learning science. This study was conducted to determine the students' achievements of biological science literacy as the total score, science competency, content, context and problems format, and the description of scientific literacy PISA comparison with students' origin school and the students' National Examination result and the factors that influence it.This research is a descriptive research. It was conducted to student grade X in SMAN 1, SMAN 8, SMAN 13 and SMAN 16 Padang. The instrument used to collect data is the text about the biological scientific literacy PISA test taken from the book Take the Test: Sample Question from the OECD's PISA Assessment. The results showed that the highest score of biological science literacy based on the total score was obtained by the students of SMAN 1 score 57.50, SMAN 8 score 45.90, SMAN 13 score 43.50 and SMA 16 score 42.40. Based on the science competency, the students are good at applying scientific evidence. The overall score of the students' science competency 48.51 (low), content $t 48.12$ (low) and context 46.82 (low) and the highest average score is in essay problem. It can conclude that the student of grade X, Senior High School in Padang have low point of students' science literacy
\end{abstract}

Keywords : Literacy scientific, Pisa results, Using reason

\section{PENDAHULUAN}

Pendidikan merupakan proses memper siapkan peserta didik menjadi anggota masyarakat yang produktif, inovatif, kreatif, mandiri, dan sukses. Semakin banyak cara yang dimiliki siswa untuk memahami dan memadukan informasi yang mereka kumpul kan, akan semakin baik mereka dapat meng gunakannya untuk memecahkan permasalah an yang dihadapi dan mengambil keputusan yang tepat pada kehidupannya di masa kini dan di masa depan. Pendidikan juga akan mampu meminimalkan bahaya yang me ngancam ke langsungan hidup mereka dan menjamin terjadinya masyarakat yang mampu hidup secara swadaya, mandiri, untuk mencapai kesejahteraan bersama.
Asal kata literasi berasal dari "literacy" yang berarti melek huruf atau gerakan pemberantasan buta huruf, sementara sains berasal dari "science" yang berarti ilmu pengetahuan atau "scientific" yang berarti ilmiah (Enchols danShadily, 1990). National Science Education Standards (1996) menyatakan "scientific literacy is knowledge and understanding of scientific concepts and processes required for personal decision making, participation in civic and cultural affairs, and economic productivity". Literasi sains (literasi ilmiah) yaitu suatu ilmu pengetahuan dan pemahaman mengenai konsep dan proses sains yang memungkinkan seseorang untuk membuat suatu keputusan dengan pengetahuan yang dimilikinya, serta turut 
terlibat dalam hal kenegaraan, budaya dan pertumbuhan ekonomi. Dengan kata lain seseorang yang melek literasi sains akan mampu berperan aktif dalam segala segi kehidupan terutama pada bidang ilmu yang digelutinya (Holbrook, and Rannikmae, 2009)

Berdasarkan pengertian tersebut, penekanan literasi sains bukan pada penguasaan pengetahuan dan pemahaman mengenai konsep dan proses dains saja, tetapi lebih mengarahkan bagaiman memungkinkan seseorang untuk dapat membuat suatu keputusan dan turut terlibat dalam kehidupan bermasyarakat ber dasarkan pengetahuan dan pemahaman sains yang dimilikinya. Literasi sains penting dimiliki setiap orang sebagai masyarakat, warga negara dan warga dunia. Setiap orang harus memiliki tingkat literasi sains tertentu agar dapat bertahan hidup di alam maupun di tempatnya bekerja. Literasi sains berkaitan dengan pengetahuan, pemahaman, keterampilan dan nilai-nilai yang terdapat di dalam sains.

Alasan mengapa literasi sains penting untuk dimiliki siswa, yaitu: (1) pemahaman sains menawarkan pemenuhan kebutuhan personal dan kegembiraan, dapat dibagikan dengan siapapun; dan (2) negara-negara di dunia dihadapkan pada pertanyaanpertanyaan dalam kehidupannya yang memerlukan informasi ilmiah dan cara berpikir ilmiah untuk mengambil keputusan dan kepentingan orang banyak yang perlu di informasikan seperti, udara, air dan hutan (Zuriani, 2013).

Berdasarkan hasil Programme for International Student Assessment (PISA) tahun 2000, 2003, 2006 dan 2009 skor literasi sains siswa Indonesia usia 15 tahun berturut-turut adalah 393, 395 dan 395 dengan skor rata-rata semua negara peserta 500 dan simpangan baku 100 (Ekohariadi, 2009). Pada PISA 2009 skor siswa Indonesia adalah 383 dengan rerata skor negara peserta adalah 501 (OECD, 2010) dan PISA 2012 dengan skor 383, berada di peringkat 64 dari 65 negara peserta.

Rendahnya skor perolehan siswa Indonesia mencerminkan rendahnya prestasi belajar IPA siswa Indonesia rata-rata sekitar $34 \%$ untuk keseluruhan, 29\% untuk konten, $34 \%$ untuk proses dan $32 \%$ untuk konteks (Firman, 2007). Hasil capaian tersebut juga mengindikasikan bahwa rata-rata kemampu an sains siswa Indonesia baru sampai pada kemampuan mengingat dan mengenali pengetahuan ilmiah berdasarkan fakta sederhana tetapi belum mampu untuk mengkomunikasikan dan mengaitkan berbagai topik sains, apalagi menerapkan konsep-konsep yang kompleks dan abstrak di dalam kehidupan sehari-hari.

Faktor lain yang menyebabkan masih rendahnya literasi sains siswa Indonesia berdasarkan penilaian PISA adalah peserta didik Indonesia belum terlatih dalam me nyelesaikan soal-soal dengan karakteristik seperti soal-soal pada PISA. Padahal untuk meningkatkan literasi sains atau literasi ilmiah, guru juga memerlukan perangkat evaluasi yang berbasis literasi sains. Guru sering mengabaikan alat evaluasi berbasis literasi sains karena belum memahami bagaimana membuat perangkat evaluasi tersebut (Fraenkel, et al. 2012). Selain itu, faktor latar belakang siswa, minat, intensitas belajar, dan sikap siswa terhadap sains juga turut mempengaruhi rendahnya prestasi literasi sains siswa (Ekohariadi, 2009).

Selain itu tingginya tingkat kesukaran soal PISA juga menjadi faktor rendahnya capaian siswa Indonesia. Tuntutan soal pada PISA melebihi tuntutan kurikulum yaitu di atas Standar Kompetensi dan Kompetensi Dasar yang menjadi Tujuan Pembelajaran di Indonesia. Menurut hasil penelitian Kurniati (2014) ada materi pada soal PISA yang tidak dipelajari oleh siswa di sekolah. Selain itu informasi yang diperoleh siswa hanya dari buku pelajaran dan guru di sekolah. 
Biologi sebagai salah satu disiplin ilmu yang memberikan pengaruh cukup besar terhadap ilmu pengetahuan ilmiah dan teknologi. Namun hasil survey mem buktikan capaian literasi sains siswa Indonesia pada masing-masing unit soal biologi PISA tahun 2000 sampai 2009 tidak jauh berbeda dengan capaian PISA secara keseluruhan. Rata-rata persentase capaian literasi sains termasuk persentase negara skor terendah, yaitu kurang dari 50\% dari skor yang ditetapkan oleh OECD (OECD, 2009).

Berdasarkan hasil wawancara penulis dengan 4 orang guru biologi dan observasi pada pembelajaran biologi di lingkungan SMAN 1, 3, 7, dan 8 di kota Padang pada bulan Agustus 2016 ditemukan bahwa sebagian besar guru belum mengetahui tentang soal PISA, dan bagaimana bentuk soal PISA dan siswa pun belum pernah mendengar informasi tentang PISA. Ketika peneliti memperlihatkan soal PISA kepada guru-guru tanggapan yang diterima peneliti dari guru merasa belum pernah milihat soal sepertri itu. Hasil wawancara dengan 20 orang siswa pada tiap sekolah tersebut diketahui rata-rata $85,5 \%$ siswa tidak suka membaca soal yang panjang-panjang karena rendahnya minat siswa dalam membaca. Biasanya soal yang diujikan kepada siswa adalah soal pilihan ganda dan soal uraian.

Beberapa peneliti terdahulu telah melakukan pengujian soal PISA dibeberapa sekolah SMP tapi belum pernah melakukan pengujian di SMA di kota Padang untuk itu penulis ingin mengetahui literasi sains siswa SMA di kota padang, apakah sama dengan siswa SMP atau sebaliknya. Mengingat pentingnya penilaian literasi sains untuk mengetahui tingkat pemahaman siswa berdasarkan memecahkan masalah, bernalar berdasarkan hipotesis, menggabungkan sejumlah informasi secara sistematis, menggunakan rasio dan logika dalam abstrak, maka penulis melakukan penelitian tentang literasi sains biologi pada siswa SMA kelas X se-kota Padang.

\section{METODE PENELITIAN}

Penelitian ini merupakan penelitian deskriptif. Penelitian ini dilakukan di empat SMA Negeri Kota Padang. Dalam hal ini penulis menetapkan 4 sekolah yaitu SMAN 1 Padang, alamat jl. Belanti Raya No. 11, Lolong, SMAN 8 Padang, alamat JL. Adi Negoro KM 18, Kayu Kalek, SMAN 13 Padang, alamat Jl. Tanjung Aur Balai Gadang Kec. Koto Tangah Padang, dan SMAN 16 Padang, alamat J1. Bukit Napa Kuranji Kec. Kuranji Padang. Pemilihan kelas dilakukan secara acak.

Pengumpulan data dilakukan dengan cara pemberian tes untuk mengetahui capaian literasi sains biologi siswa. Data tentang faktor yang mempengaruhi capaian literasi sains didapatkan dengan cara wawancara terhadap guru dan siswa secara terpisah. Semua data yang diperoleh dianalisis secara kuantitatif dan kualitatif. Data yang diperoleh dari tes literasi sains biologi diolah secara kuantitatif dan data yang diperoleh dari wawancara diolah secara kualitatif. Teknik pemeriksaan keabsahan data menggunakan teknik triangulasi.

\section{HASIL DAN PEMBAHASAN}

\section{Hasil Tes Literasi Sains Biologi}

Tabel 1. Capaian Literasi Sains Biologi Berdasarkan Skor Rata-rata

\begin{tabular}{|c|c|c|c|c|c|} 
No & SMA & SkorRata-rata & Kategon & Nilai & Kategon \\
\hline 1. & 1 & 36,80 & Tuntas & 57,50 & Rendah \\
\hline 2. & 8 & 29,41 & Tidak Tuntas & 45,90 & Rendah \\
\hline 3. & 13 & 27,87 & Tidak Tuntas & 43,50 & Rendah \\
\hline 4 & 16 & 27,17 & Tidak Tuntas & 42,40 & Rendah \\
\hline 4. & Gabungan & 30,31 & Tidak Tuntas & 47,32 & Rendah \\
\hline
\end{tabular}

Berdasarkan Tabel 1, literasi sains siswa SMAN 1 tuntas dalam menjawab soal 
PISA namun ke tiga SMAN yang lainnya tidak tuntas dalam menjawab soal PISA karena skor pada masing-masing sekolah tidak mencapai standar skor ketuntasan soal yaitu 32. Walaupun siswa SMAN 1 memiliki skor rata-rata tuntas namun nilai literasi sainsnya masih dikategorikan rendah, sama dengan SMAN 8,13 dan 16. Kategori nilai dikatakan tinggi apabila besar dari 75, kategori nilai dikatakan sedang antara 60 dengan 75, namun ke empat SMAN nilainya kecil dari 60 maka termasuk dalam kategori rendah.

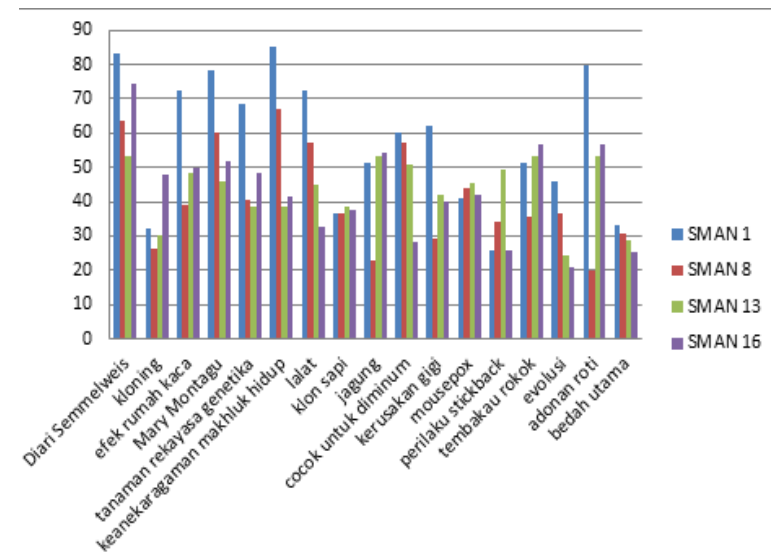

Gambar 1. Capaian Literasi Sains Biologi Berdasarkan Tema

Berdasarkan Gambar 1, diketahui bahwa capaian nilai siswa pada setiap tema dalam soal PISA biologi dianalisis untuk mengetahui wawasan, pengetahuan dan penguasaan siswa pada setiap materi yang disajikan pada naskah soal PISA. Perbedaan antara SMAN 1, 8, 13 dan 16 dalam men jawab soal masing-masing tema adalah siswa SMA 1 dapat menjawab soal tema 1 , $3,4,5,6,7,9,10$ dengan tingkat kesukaran soal sedang, dan tema 16 dengan tingkat kesukaran soal sukar. Siswa SMAN 8 dapat menjawab soal tema $1,4,6,7,10$ dengan tingkat kesukaran soal sedang. Siswa SMAN 13 dapat menjawab soal tema 1,9 dengan tingkat kesukaran soal sedang dan tema 13, 14, 16 dengan tingkat kesukaran soal sulit. Sedangkan siswa SMAN 16 dapat menjawab soal tema $1,3,4$, 9, dengan tingkat kesukaran soal sedang dan tema 14, 16 dengan tingkat kesukaran soal sulit. Secara umum ke empat sekolah dapat menjawab soal kategori sedang. Namun rata-rata gabungan literasi sain PISA berdasarkan tema kecil dari 60 dengan kategori rendah.

\section{Capaian Literasi Sains Berdasarkan Aspek Kompetensi Sains, Aspek Konten dan Aspek Konteks Biologi}

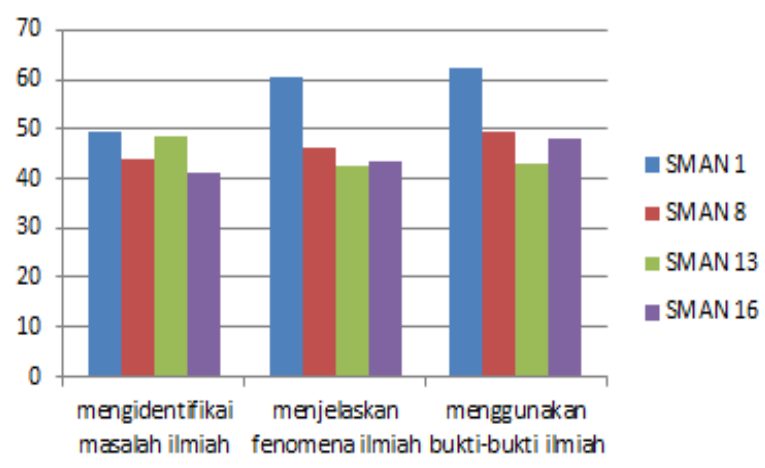

Gambar 2. Capaian Literasi Sains Siswa Berdasarkan Aspek Kompetensi Sains

Berdasarkan Gambar 2, dapat di ketahui bahwa skor siswa SMAN 1, 8, 13 dan 16 tidak ada satu pun yang tuntas menjawab soal-soal tentang Menjelaskan Fenomena Ilmiah karena skor masingmasing sekolah kecil dari 255 sedangkan skor yang harus dicapainya besar dari 255 . Nilai literasi sain biologi berdasarkan aspek menjelaskan Fenomena Ilmiah juga masih rendah.

Pada aspek menjelaskan fenomena ilmiah SMA 1 mencapai skor ketuntasan karena skornya besar dari 465 sedangkan siswa SMAN 8,13 dan 16 tidak mencapai skor ketuntasan. Nilai literasi sains biologi siswa SMA 1 mendapatkan nilai dengan kategori sedang karena nilainya besar dari 60, sedangkan tiga SMAN yang lain nilainya kecil dari 60 dan termasuk kedalam kategori rendah. Nilai literasi pada aspek menjelaskan fenomena ilmiah gabungan ke empat sekolah masih dalam kategori rendah. 
SMAN 1, 13 dan 16 tuntas mengerja kan soal menggunakan bukti ilmiah, sedangkan SMAN 13 tidak tuntas mengerjakan soal ini. SMAN 1 memiliki nilai rata-rata literasi sains berdasarkan menggunakan bukti ilmiah termasuk dalam kategoti sedang karena nilainya besar dari 60, sedangkan SMA 8,13 dan 16 termauk dalam kategori rendah karena nilainya kecil dari 60,00 .

Capaian literasi sain biologi berdasarkan komperensi sains rata-rata grafik siswa SMAN 1 lebih tinggi dari ke tiga SMAN lainnya. Sedangkan siswa SMAN 8, 13 dan 16 rata-rata tinggi grafinknya hampir sama. Apabila di gabungkan nilai kompetensi sains ke empat sekolah, nilai rata-rata yang di dapat 48, 51. Nilai ini kecil dari 60. Oleh karena itu kemampuan siswa SMAN kelas $\mathrm{X}$ se kota padang memahani aspek kompetensi sains masih rendah.Nilai rata-rata tertinggi yang dicapai siswa adalah pada aspek menggunakan bukti-bukti ilmiah. Sedangkan nilai rata-rata terendah pada aspek mengidentifikasi masalah ilmiah.

\section{a) Aspek Konten}

Tabel 2. Capaian Literasi Sains Biologi Berdasarkan Aspek Konten

\begin{tabular}{|c|c|c|c|c|c|}
\hline No & SMA & Skor & Kategori & Nillai & Kategori \\
\hline 1. & 1 & 400 & Tuntas & 57,23 & Rendah \\
\hline 2. & 8 & 346 & Tuntas & 47,01 & Rendah \\
\hline 3. & 13 & 298 & Tidak Tuntas & 43,18 & Rendah \\
\hline 4 & 16 & 311 & Tidak Tuntas & 45,07 & Rendah \\
\hline 4. & Gabungan & 338,75 & Tidak Tuntas & 48,12 & Rendah \\
\hline
\end{tabular}

Skor ketuntasan 345

Berdasarkan Tabel 2. nilai literasi sain berdasarkan aspek konten SMAN 1 dan SMAN 8 tuntas namun nilainnya masih kategori rendah karena kecil dari 60. SMAN 13 dan 16 tidak tuntas pada aspek konten dan nilainya pun masuk ketegori rendah. Hal tersebut menunjukkan kemampuan yang dimiliki oleh siswa dalam memahami soal berdasarkan bidang-bidang fenomena alam masih rendah.

SMAN 1 tuntas dalam menjawab soal pada aspek konteks namun nilai literasi sains siswa masih rendah karena kecil dari 60, sedangkan SMAN 8, 13 dan 16 tidak tuntas dalam menjawab aspek ini dan nilai literasi sainsnya juga rendah. Hal tersebut menunjukkan kemampuan yang dimiliki oleh siswa dalam memahami soal berdasarkan bidang-bidang aplikasi sains masih rendah.

Tabel 3. Capaian Literasi Sains Biologi berdasarkan Butir Soal

\begin{tabular}{|c|c|c|c|c|c|c|}
\hline \multirow{2}{*}{ No } & \multirow{2}{*}{ Format Soal } & \multicolumn{5}{|c|}{ Nillai Rata-rata } \\
\cline { 3 - 7 } & SMA 1 & SMA 8 & SMA 13 & SMA 16 & $\begin{array}{c}\text { Gabung } \\
\text { an }\end{array}$ \\
\hline (1) & \multicolumn{1}{|c|}{$(2)$} & $(3)$ & $(4)$ & $(5)$ & $(6)$ & $(7)$ \\
\hline 1. & Pilihan ganda & 66,31 & 39,96 & 46,61 & 44,21 & 49,27 \\
\hline 2. & $\begin{array}{l}\text { Pillhan } \\
\text { Majemuk }\end{array}$ & 56,96 & 39,58 & 38,44 & 49,33 & 41,89 \\
\hline 3. & Uraian & 61,22 & 55,10 & 44,77 & 34,44 & 65,2 \\
\hline \multicolumn{2}{|c|}{ Total } & 167,75 & 134,61 & 129,82 & 127,98 & 560,16 \\
\hline \multicolumn{2}{|c|}{ Ratararata } & 56,95 & 44,87 & 43,27 & 42,66 & 46,93 \\
\hline \multicolumn{2}{|c|}{ Kategori } & Sedang & Rendah & Rendah & Rendah & Rendah \\
\hline
\end{tabular}

Berdasarkan Tabel 3, dapat diketahui bahwa SMAN 1 memiliki nilai tertinggi pada masing-masing format soal yaitu pilihan ganda, uraian dan pilihan majemuk, pilihan ganda mempunyai grafik tertinggi. SMAN 8 nilai tertinggi adalah soal uraian, selanjutnya pilihan ganda dan paling rendah adalah pilihan majemuk. Sama dengan SMAN 1 pilihan majemuk juga format soal terendah, hal ini terjadi karena siswa tidak terbiasa menjawab soal seperti soal majemuk.

SMAN 13 nilai tertinggi adalah pilihan pilihan ganda, diikuti dengan uraian dan pilihan majemuk memiliki nilai terendah, sama dengan SMAN 1 dan 8 padang. Berarti siswa SMAN 8 lebih memahami menjawab soal pilihan ganda dan uraian dari pada pilihan majemuk. Sedangkan SMA 16 nilai tertinggi pada 
format majemuk dan rendah pada format ganda dan uraian.

Berdasarkan skor gabungan ke empat SMAN fotmat soal uraian memiliki skor rata-rata tertinggi namun masih dalam kategori sedang karena nilainya antara 6075. Dapat disimpulkan siswa lebih mudah menjawab sooal uraian dari pada pilihan ganda dan pilihan majemuk.

Tabel 4. Perbandingan Nilai Literasi Sains PISA siswa Kelas $X$ se Kota Padang dengan Asal Sekolah dan Nilai UN SMP

\begin{tabular}{|l|c|c|c|c|}
\hline No & $\begin{array}{c}\text { Nama } \\
\text { Sekolah }\end{array}$ & $\begin{array}{c}\text { Rata-Rata Nilai } \\
\text { UN }\end{array}$ & $\begin{array}{c}\text { Skor Total } \\
\text { Literasi Sains }\end{array}$ & Kategori \\
\hline 1 & SMAN 1 & 35,89 & 57,50 & Rendah \\
\hline 2 & SMAN 8 & 32,37 & 45,90 & Rendah \\
\hline 3 & SMAN 13 & 29,14 & 43,50 & Rendah \\
\hline 4 & SMAN 16 & 29,03 & 42,40 & Rendah \\
\hline
\end{tabular}

Berdasarkan Tabel 4 dapat diketahui bahwa rata-rata UN tertinggi dan nilai literasi sains tertinggi adalah SMAN 1 Padang. Yang memiliki Akreditasi A. Ratarata nilai UN dan literasi sain siswa SMAN 8 padang lebih tinggi dari siswa SMAN 13 kedua SMA tersebut memiliki akreditasi B, Sedangkan siswa SMAN 16 memiliki nilai UN dan nilai literasi sain terendah namun memiliki akteditasi sekolah A.

Siswa SMAN 1 secara keseluruhan berasal dari SMP favorit yang memiliki akreditasi A dengan rata-rata UN 35,89. Siswa SMAN 8 merupakan siswa menengah yang berasal dari SMP berakreditasi A dan $\mathrm{B}$, sehingga nilai literasi sainsnya juga dibawah SMA 1 yaitu 45,90. Siswa yang berasal dari SMA 13 dan SMA 16 merupakan siswa yang memiliki rata-rata UN yang hampir sama namun berasal dari SMP yang secara umum berakreditasi B.

\section{Faktor-faktor yang Mempengaruhi Capaian Literasi Sains Biologi.}

Wawancara dengan guru bertujuan untuk mengetahui persepsi guru terhadap capaian siswa dalam tes literasi sains biologi, ketertarikan, sikap, factor-faktor yang mempe- ngaruhi capaian literasi sains biologi. pada tes. Berdasarkan hasil wawancara faktor yang mempengaruhi capaian literasi sains biologi siswa adalah sebagai berikut ini:

1) Siswa belum pernah mengerjakan soal literasi sains sebelumnya, sehingga membuat siswa merasa canggung dengan soal yang berbeda dari yang biasa diperoleh disekolah.

2) Kebiasaan siswa lebih suka menghapal materi pembelajaran dari pada memahaminya, sehingga siswa kurang memahami dan mengaplikasikan materi tersebut dalam kehidupan sehari-hari.

3) Soal yang biasa diberikan guru untuk evaluasi belum merupakan soal analisis, sehingga belum menuntut siswa untuk menggu- nakan penalarannya. Hal ini mengakibatkan siswa tidak terbiasa menalar dan berfikir kritis.

4) Kurangnya minat membaca siswa dan tidak terbiasanya siswa menjawab soal dalam bentuk wacana, grafik, dan gambar.

5) Siswa lebih suka menjawab soal pilihan ganda dibandingkan dengan uraian. Pada soal pilihan siswa hanya perlu memilih tanpa harus memikirkan jawaban.

\section{KESIMPULAN}

1. Capaian literasi sains biologi berdasarkan skor total siswa kelas X SMA Negeri sekota Padang berdasarkan perolehan tes menunjukkan bahwa siswa kelas $\mathrm{X}$ SMANegeri 1 Padang memperoleh nilai rata-rata paling tinggi yaitu 57,50 dengan kategori srendah. Diikuti oleh siswa kelas $\mathrm{X}$ SMANegeri 8 dengan nilai 45,90, 
SMANegeri 13 dengan nilai 43,50dan SMANegeri 16 dengan nilai 42,40 dengan kategori rendah. Capaian literasi sains gabungan ke empat sekolah adalah 47,82 dengan kategori rendah

2. Capaian literasi sains biologi berdasarkan Tema siswa kelas X SMA Negeri se-kota Padang berdasarkan perolehan tes menunjukkan bahwa Tema yang paling dikuasai Diari Semmelwais, efek rumah kaca, Mary Montagu, jagung, tembakau pada rokok serta adonan roti.

3. Capaian literasi sains biologi berdasarkan kompetensi sains siswa kelas $\mathrm{X}$ SMANegeri se-kota Padang berdasarkan perolehan tes menun- jukkan bahwa kompetensi sains yang paling dikuasai siswa adalah menggu- nakan bukti-bukti ilmiah dengan nilai 50,78 kategori rendah. Aspek konten siswa rendah $(48,12)$. Aspek konteks siswa rendah $(46,82)$

4. Capaian literasi sains biologi berdasarkan format soal siswa kelas X SMANegeri se-kota Padang berdasarkan perolehan tes menun- jukkan bahwa format soal yang banyak dijawab benar oleh siswa adalah soal dengan format uraian dengan nilai 62,3 dengan kategori rendah.

5. Deskripsi perbandingan literasi sains PISA dengan asal sekolah siwa dan nilai Ujian Nasional siswa: nilai UN sebanding dengan hasil tes PISA, apabila nilai UN siswa bagus maka nilai literasi sains biologi siswa juga bagus. Faktor yang mempengaruhi capaian literasi sains biologi siswa yaitu: minat, intensitas belajar, cara belajar, minat membaca, sikap siswa terhadap sains, kebiasaan belajar dan cara guru mendidik siswa.

DAFTAR PUSTAKA
Chabalengula, VM., F Mumba., T Lorsbach, \& C Moore. 2008. Curriculum and instructional validity of scientific literacy themes covered in zambian highschool biology curriculum. International Journal ofEnviron- ment \& Science Education 3 (4):207220.

Echols, J.M., dan Shadily, H. 1990. Kamus Inggris Indonesia. PT. Gramedia: Jakarta.

Ekohariadi. 2009. Faktor-faktor yang Mempengaruhi Literasi Sains Siswa Indonesia Berusia 15 Tahun. Jurnal Pendidikan Dasar.

Firman, H. 2007. Laporan Analisis Literasi Sains Berdasarkan Hasil StudiPisa Nasional Tahun 2006. Jakarta: Pusat Penilaian Pendidikan Balitbang Depdinas.

Fraenkel, J.R., Wallen, N.E., and Hyun, H.H. 2012. How to Design and Evaluate Research in Education. Mc Graw-Hill Press. New York.

Holbrook, J, and Rannikmae. 2009. The Meaning of Scientific Litaray. International Journal of Environment and Science Education. Vol. 4 (online) diakses tanggal 11 Desember 2015.

Kurniati, L. 2014. Analisis Capaian

Literasi Sains Biologi PISA Di SMPN 1 Padang dan SMAN 1 Padang. Tesis. Padang: UNP.

National Science Education Standards (NSES). 1996. National Academy of Science. Washington, D.C: National Academy Press.

OECD. 2009.PISA 2006. Technical Report(Online).(http://www.oecd.org, diakses pada Tang- gal 11 Desembae 2015).

PISA 2009 Results: Executive Summary. (Online)

http://www.oecd.org/pisa/pisaproducts /46619703.pdf, diakses tanggal 23 November 2015). 
Rohayati, T. 2013. Pengaruh pembelajaranInteraktif Demontrasi Terhadap Peningkatan Literasi Sains dan Sikap ilmiah Siswa SMP Pada Materi Transportasi Tumbuhan. Tesis. Bandung: Universitas Pendidikan Indonesia.

Shwartz, Y, Ben-Zvi, R, and Hofstein, A. 2006. "The Use Of Scientific Literacy
Taxonomy For Assessing The Develop-ment Of Chemical Literacy Among HighSchool Students". Chemical Educational Research and Practice. 7. (4). 203-225.

Zuriyani, E., 2013. Literasi Sains DanPendidikan. Makalah: Kemenag Sumatera Selatan. 